\title{
Gymnasielæreres forståelse af karrierelæring - en Koselleck inspireret begrebshistorisk analyse
}

\author{
Randi Boelskifte Skovhus ${ }^{1 *}$, Laura Cordes Felby ${ }^{2}$ \\ ${ }^{1}$ Forskningscenter for pædagogik og dannelse, VIA University College, Danmark \\ ${ }^{2}$ Center for Undervisningsudvikling og Digitale Medier, Aarhus Universitet, Danmark \\ * Correspondence: ras@via.dk
}

\begin{abstract}
Abstrakt
Formålet med denne artikel er at give indsigt $\mathrm{i}$, hvordan gymnasielærere forstår karrierelæring som et nyt begreb i den lov, der rammesætter undervisningen i gymnasiet, samt hvordan deres forståelse relaterer sig til et $\emptyset n s k e$ om opretholdelse af en meningsfuld praksis. Artiklens empiri baserer sig på et forsknings- og udviklingsprojekt, hvor gymnasielærere st øttet ved metoden forskningscirkler, arbejder med at forstå begrebet karrierelæring og udvikle deres undervisningspraksis i forlængelse heraf. Det teoretiske fundament bygger på Reinhart Kosellecks begrebshistorie, hvorigennem det bliver muligt at analysere og diskutere, hvordan begrebet karrierelæring tilskrives mening, samt hvordan erfaringer med og forventninger til de politiske og sociale strukturer er med til at forandre og udvikle begrebet. Med analysen identificeres fem meningskategorier, der diskuteres med særligt fokus på kompleksiteten i begrebsliggørelsen og udmøntning i praksis.
\end{abstract}

\section{English abstract}

The objective of this article is to offer insight into how upper secondary teachers interprets 'career learning' as a new educational concept, and how their understanding refers to a wish to maintain a meaningful educational practice. The empirical foundation is based on a development project, where teachers develops their understanding of career learning in relation to their practice. The theoretical foundation is Kosellecks conceptual history, which illuminates how career learning is attributed a certain meaning, and how the political and social structures is contributing to this development. Five categories in which the concept is articulated are detected and discussed.

Keywords: karrierelæring; vejlednings- og uddannelsespolitik; forskningscirkler; Koselleck

\section{Introduktion}

Før industrialiseringen var det for mange børn og unge givet, hvordan deres fremtidige karrierevej ville forme sig. Var faderen tømrer var forventning at sønnen blev tømrer. Var moren husmor var 
forvetningen, at datteren blev husmor. Med industrialiseringen i 1800-tallet flyttede mange til byerne og nye jobmuligheder åbnede sig med en mekanisering af produktionen. Med mindre givne livsbaner $\mathrm{i}$ et samfund under hastig forandring blev Parsons (1854-1908) og andre optaget af, hvordan borgerne bedst kunne hjælpes til at finde beskæftigelse, hvor de kunne nå deres fulde potentiale. Særligt var Parsons optaget af at hjælpe unge, kvinder og fattige til at finde en beskæftigelse, hvor de kunne forbedre deres tilværelse. Erhvervsvejledningen udsprang som sådan af et ønske om at skabe et mere socialt retfærdigt samfund (Arthur et al., 2013, s. 136; Plant \& Kjærgård, 2016). Også i dag lever børn, unge og voksne i et komplekst samfund og går en kompleks fremtid i møde med konstante forandringer og vedvarende krav om fleksibilitet, hurtig omstilling og geografisk mobililitet. Der er forventninger om at borgerne løbende erhverver sig nye kvalifikationer, følger med den hastige teknologiske udvikling og ikke skal regne med at kunne uddanne sig til noget, som de kan arbejde med indtil de går på pension. Arbejdsmarket er med andre ord et kaotisk system, som ikke er muligt at forudsige, og hvor videns $\emptyset$ konomi, globalisering og øget global konkurrence er centrale faktorer for forandringerne (Pryor \& Bright, 2014). Samtidig fremhæves nødvendigheden af vedholdenhed, så unge eksempelvis kan gennemføre den uddannelse, de er påbegyndt, og af at de kan håndtere deres hverdagsliv og skabe en balance med uddannelse, fritidsarbejde, fritidsinteresser, venner og familie.

I skole og uddannelsessystemet er der stadig en optagethed af at understøtte at børn og unge udvikler livsbaner, der er til glæde for dem selv og samfundet. Der er et $\emptyset$ nske om at understøtte, at børn og unge får indsigt i verden, udvikler værdier, forstår sig selv i en kontekst og udvikler et grundlag, der ruster dem i deres videre færd i uddannelsessystemet, på arbejdsmarkedet og i livet som helhed.

I karrierevejledningsfeltetii, som er udviklet siden den spæde begyndelse i 1800-tallet, og som denne artikel tager sit afsæt i, er der en række begreber, der betegner menneskers arbejde med at få indsigt i deres muligheder, deres kontinuerlige arbejde med at håndtere samspillet mellem uddannelse, arbejde og det Øvrige liv og med at træffe de valg, der knytter sig hertil. Ligeledes er der en række begreber, der betegner de indsatser som lærere og vejledere sætter i værk i forhold til at understøtte ovenstående. Der er tale om begreber som karriere, karrierelæring, karriereudvikling, career management skills, karrierekompetence, karriere management, career education og karrierevejledning. I en nordisk kontekst arbejdes der, som også i andre lande, på forsknings- og policyniveau med at udvikle forståelser af, hvordan centrale begreber kan defineres og være relevante og hjælpsomme for både policy og praksis. Eksempelvis udarbejdede Thomsen et notat for NVL og ELGPN, hvor hun udfoldede, hvordan karrierekompetence/CMS kan forstås i en nordisk kontekst (Thomsen, 2014). Aktuelt arbejder Kompetanse Norge med at udvikle et kvalitetsrammeværk for karrierevejledning hvori en model for karrierelæring i kontekst bl.a. præsenteres (Kompetanse Norge, 2019). Et andet eksempel findes ved Haug, der fremhæver karrierekompetence, karrierelæring og karriereundervisning som sammensatte og mangesidige begreber, som er centrale for politikudformning og praksis i karrierevejledningsfeltet, og udfolder i forlængelse heraf, hvordan begreberne kan forstås og spiller ind i praksis (Haug, 2018). I en dansk kontekst udfolder Skovhus, hvordan begreber i karrierevejledningsfeltet kan forstås og spiller sammen med unges oplevelse af mening i de karrierevejledningsindsatser de møder (Skovhus, 2018).

Endvidere anvendes forskellige betegnelser for de professionelle, som arbejder med at hjælpe mennesker med deres karriere, for eksempel vejledere og mentorer. I en engelsksproglig sammenhæng anvendes begreber som careers advisers, careers educators, careers counsellors, career consultants og career practitioners. For andre faggrupper udgør dét at hjælpe mennesker med deres karriere en vigtig del af deres job uden det er deres hovedfokus. Dette kan eksempelvis gøre sig gældende for lærere, studiesekretærer og HR-medarbejdere (Hooley, 2013, s. 4).

Begreberne, der anvendes indenfor karrierevejledningsfeltet, er mange, overlappende og anvendes forskelligt af forskellige aktører (Hughes et al., 2016; Irving, 2015, s. 299; Lejonberg \& Føinum, 2018). Eksempelvis kan der være variationer mellem lande i forhold til hvordan begreber forstås og anvendes (Hooley, 2013, s. 4), ligesom variationer i begrebernes anvendelse og forståelse i andre sammenhænge kan afspejle forskellige teoretiske og filosofiske forståelser samt politiske afsæt inden for karrierevejledningsfeltet (Sultana, 2013, s. 69). 
Watts peger på, at inkonsistensen i begrebsbrug rækker ind i policy og fremhæver, at 'the language used to describe career development in relation to public policy is varied and often confusing' og argumenterer for at et klart sprog er essentielt for kommunikationen i karrierevejledningsfeltet og til parter udenfor dette og at 'some branding based on core concepts is needed, to support consistency, coherence and continuity' (Watts, 2011, s. 3).

Også i en dansk sammenhæng er der mange begreber i spil i feltet, ligesom begreber fra feltet indføres i kontekster, hvor de ikke har gjort sig gældende før. Eksempelvis er karrierelæring et nyt begreb i en dansk gymnasial sammenhæng. Begrebet blev i 2016 skrevet ind i Aftale om styrkede gymnasiale uddannelser (Regeringen et al., 2016), hvilket dannede grundlag for lovændringen omkring de gymnasiale uddannelser med ikrafttrædelse skoleåret 2017 (Undervisningsministeriet, 2016).

Artiklens forfattere er optaget af, hvordan gymnasielærerne forstår begrebet karrierelæring $i$ en gymnasiepraksis. Artiklen undersøger forskningsspørgsmålene: Hvordan forstår gymnasielærere et nyt begreb i den lov, der rammesætter undervisningen i gymnasiet, nemlig karrierelæring? Hvordan relaterer deres forståelse sig til et ønske om opretholde en praksis, som de oplever meningsfuld?

I artiklen anvendes Reinhart Kosellecks begrebshistoriske analyse som analytisk værktøj. Koselleck peger på, at det ligger $i$ et begrebs natur, at der ikke kan defineres en endelig mening med et begreb, ligesom begreber er foranderlige på tværs af tid og kontekst (Koselleck, 2007, s. 106). Dette uddybes senere i artiklen, men vi vil her fremhæve, at det med dette teoretiske udgangspunkt in mente, ikke er ærindet med artiklen at diskutere og definere en normativ forståelse af, hvordan karrierelæring skal forstås teoretisk, men derimod at præsentere gymnasielærernes forståelse af karrierelæring og deres oplevelse af begrebets relevans og meningstilskrivelse i forhold til egen praksis.

\section{Det danske uddannelsessystem og loven om karrierelæring i gymnasiet}

I Danmark er der 10 års undervisningspligt. Børn går i skole fra 0. til 9. klasse (alderen 5/6 år til 15/16 år) og kan vælge at fortsætte i 10. klasse. I den sidste del af grundskolen modtager de unge uddannelsesvejledning og træffer et valg om, hvorvidt de vil påbegynde en erhvervsfaglig uddannelse eller en gymnasial uddannelse. De erhvervsfaglige uddannelser giver erhvervskompetence, mens de gymnasiale uddannelser giver studiekompetence og adgang til videregående uddannelser. Der er fire gymnasiale uddannelser; hf, som er to-årig, og htx, hhx og stx, som alle er treårige. På de erhvervsfaglige uddannelser er det endvidere muligt at vælge fag på gymnasialt niveau og derved få adgang til udvalgte videregående uddannelser. Fokus i nærværende artikel er gymnasieformerne stx, htx og hhx. Stx (almen studentereksamen) tilbyder ud over de almene fag som dansk og matematik en bred vifte af fag inden for samfundsvidenskab, naturvidenskab og humaniora som for eksempel religion, oldtidskundskab, idræt og musik. Htx (teknisk studentereksamen) har fokus på tekniske og naturvidenskabelige fag samt kommunikation og it kombineret med almene fag som dansk og matematik. Hhx (merkantil studentereksamen) har særligt fokus på fag som økonomi, handel, erhvervsjura og sprog kombineret med almene fag (Undervisningsministeriet, 2019). Af de tre gymnasieformer har htx og hhx størst kontakt og samarbejde med erhvervslivet.

De tre treårige ungdomsuddannelser blev med en gymnasiereform i 2016 (med ikrafttrædelse ved skoleåret 2017) underlagt samme bekendtgørelse. Det betyder, at de alle har det samme overordnede formål, hvilket er at 'forberede eleverne til videregående uddannelse, herunder at de tilegner sig almendannelse, viden og kompetencer gennem uddannelsens kombination af faglig bredde og dybde og gennem samspillet mellem fagene.' (Undervisningsministeriet, 2016). Med den nye gymnasiereform var der et $\varnothing$ nske om at styrke elevernes faglighed og dannelse - 'i lyset af samfundsudviklingen' - blandt andet ved at 'fremhæve, understrege og opdatere (...) elevernes faglige kundskaber og kompetencer' inden for eksempelvis karriere (Regeringen et al., 2016).

Hvordan karriere rammesættes i forskellige policy-dokumenter for gymnasieskolen varierer. I aftaleteksten benævnes det gennem karrierekompetencer, der skal styrkes gennem karrierelæring. Her fremgår det, at karrierelæring skal give eleverne indsigt i fagenes anvendelse, give dem konkrete 
erfaringer med faget i praksis, give bedre muligheder for praktikophold og samarbejde med institutioner og virksomheder, samt gennem bedre muligheder for individuel vejledning. Eleverne skal dermed opnå 'forståelse for egne karriereperspektiver og mulige uddannelsesvalg.' (Regeringen et al., 2016). I selve bekendtgørelsen (Undervisningsministeriet, 2016) betegnes 'karriere' hverken gennem karrierekompetencer eller karrierelæring, men derimod som et 'studie-/karriereperspektiv og et personligt perspektiv', der skal styrke elevernes 'evne til at håndtere valg og overgange i uddannelsessystemet', give dem viden om og erfaringer med fagenes anvendelse, hvilket 'modner deres evne til at reflektere over egne muligheder og at træffe valg om egen fremtid'. Karriereperspektivet er desuden udfoldet meget forskelligt i fagenes læreplaner både i forhold til omfang og i forhold til didaktiske grundspørgsmål.

Der er således forskellige perspektiver og begreber på spil i policy, hvilket øger kompleksiteten, når lærerne skal arbejde begrebet ind i deres praksis. Overordnet set kan det dog siges, at der i de politiske dokumenter primært er fokus på uddannelsesvalg, overgange og fagenes anvendelse.

\section{Udviklingsprojektet som udgør artiklens empiri}

De tre gymnasieformer stx, hhx, htx i en større dansk by har valgt at arbejde sammen med det formål at give lærerne et kompetenceløft med henblik på at implementere karrierelæring i den daglige undervisning. Dette skete i udviklingsprojektet 'Implementering af karrierelæring i undervisningen på hhx, htx og stx'. Udviklingsprojektet har endvidere som formål at opbygge et samarbejde mellem faglærerne på hhx, htx og stx og StudievalgDanmark med henblik på at skabe meningsfulde sammenhænge mellem den undervisning og vejledning eleverne modtager, samt at opbygge et samarbejde mellem lærerne på de tre gymnasieformer for at drage nytte af de forskellige tilgange til karrierelæring, der forventes at være på skolerne.

Udviklingsprojektet indledes med, at lærerne får et fagligt oplæg omkring karrierelæring ved en forsker fra en dansk professionshøjskole. Herefter arbejder lærerne med praksisudvikling af deres undervisning. Udviklingsarbejdet underst $\varnothing$ ttes af forskningscirkler. Forskningscirkler er en participatorisk metode, hvor praktikere og forskere mødes for at udveksle teori, forskningsbaserede viden og viden om praksis. På baggrund af dette udvikles og gennemføres indsatser og eksperimenter i egen praksis. Dette sker for at skabe ny viden og udvikle praksis. Ambitionen er at skabe en fremadskridende bevægelse mellem praksis, udforskning, kvalificering og yderligere udvikling af indsatser i praksis (Persson, 2009). I det aktuelle udviklingsprojekt arbejder lærerne sammen med fagkollegaer i forskningscirkler, som ledes af gymnasiernes pædagogiske ledere eller en kollega til nogle af de deltagende lærere. Lærerne deltager i fire forskningscirkelmøder, hvor lærerne og forskningscirkellederen drøfter karrierelæringsteori ligesom lærerne præsenterer deres udviklingsarbejde og de praksisafprøvninger de arbejder med i projektet. Fagkollegaer og forskningscirkelleder drøfter og giver feedback på udviklingsarbejde og praksisafprøvninger som grundlag for videreudvikling af arbejdet med at implementere karrierelæring i undervisningen.

I nærværende artikel er der fokus på udviklingsarbejdet omkring faget engelsk og lærernes meningstilskrivelse af karrierelæring, som det kommer til udtryk til forskningscirkelmøderne omkring karrierelæring i engelskundervisningen.

\section{Kosellecks begrebshistorie - artiklens teoretiske grundlag}

Artiklens teoretiske og analytiske afsæt er Reinhart Kosellecks begrebshistorie. Koselleck (1923-2006) var professor i historisk teori på University of Bielefeld i Tyskland. Koselleck er anerkendt for sin udvikling af begrebshistorien, med hvilken han blandt andet undersøger, hvordan begreber skabes, forandres og nyskabes gennem politiske og sociale strukturer.

Omdrejningspunktet i Kosellecks begrebshistoriske analyser er at fremstille begrebers 'konstant foranderlige rum eller horisonter af mulige betydninger. Med ordet og dets betydninger som heuristisk trinbræt er det Kosellecks ambition til stadighed at afdække, hvilke tanker der har kunnet tænkes, og 
hvilke handlinger der har kunnet legitimeres i forskellige historiske situationer' (Nevers \& Olsen, 2007, s. 19). Koselleck skelner mellem sprog og ikke-sprog - mellem begreb og kontekst - hvor begreber udvikles i et spændingsforhold til kontekst.

Koselleck udvikler sin teori til at beskrive og lave historiske analyser af overgangen til moderne tid (ca. 1750-1850). Hans ambition er at udvikle en teori om historisk tid, hvor 'historien ikke bør forstås som én lineær bevægelse, men derimod som lag af tidslige strukturer, der med forskellig varighed, hastighed og styrke griber ind $\mathrm{i}$ hinanden, og at historien netop udspiller sig $\mathrm{i}$ en konstant interaktion mellem disse tidslige lag' (Koselleck, 2007, s. 15). Koselleck fremhæver, at mennesker skaber og accelererer historien og dermed bliver definitionen af begreber til på en kampplads, da begrebsforståelsen er definerende for fremtiden: 'Når begreberne begynder at gribe ud i fremtiden, bliver kampen om at definere fremtiden nemlig også en kamp om at definere begreberne (Koselleck, 2007, s. 13).

Kosellecks teori er således udviklet til at analysere overgangen til moderne tid. Han angiver ikke, at begreber opfører sig og besættes på samme måde efter det 19. århundrede og dermed forholder han sig ikke til om nutidige begreber kan analyseres efter samme metode. Koselleck er dog anvendt $\mathrm{i}$ nutidige uddannelsesvidenskabelige og politiske analyser af eksempelvis Linné som analyserer curriculum teori og didaktik (Linné, 2015) og Tveit som analyserer hvordan forældre forstår deres egen rolle, lærernes rolle og samtaler mellem forældre og lærere (Tveit, 2009).

I nærværende artikel anvender vi dele af Kosellecks forfatterskab, som analytiske værktøjer til at analysere og diskutere de forskellige meningstilskrivelser gymnasielærere har af begrebet karrierelæring. I det nedenstående præsenterer vi i relation hertil centrale aspekter af Kosellecks teori, herunder; word (signification) - meaning (concept) - object (Koselleck, 1985, s. 108). I vores oversættelse; ord (betegnelse) - begreb (mening) $)^{\text {iii }}$ - kontekst (sagsforhold).

Ord kan have forskellige betydninger, men $\mathrm{i}$ brug er de entydige, hvorimod begreber fordrer flertydighed og udvikles i kontekst. 'Et begreb bundter den historiske erfarings mangfoldighed med en sum af teoretiske og praktiske forhold til en sammenhæng, der som sådan kun er givet - og kan erfares - ved begrebet' (Koselleck, 2007, s. 72). Begreber forener rigdomme af betydninger, og det ligger således $i$ et begrebs natur, at den endelige mening ikke kan defineres samt at begreber er foranderlige på tværs af tid og kontekst (Koselleck, 2007, s. 106). Dette betyder, at når aktører tilskriver et begreb mening, kan det ses som en positionering og som en del af at skabe kollektive identiteter. Koselleck viser således, at begreber beskriver både sociale og politiske forhold. 'Sproget henviser til noget i verden' (Ifversen, 2007, s. 85), og der er en kontekst eller et sagsforhold uden for begreberne, som begreberne står $i$ et forhold til (Ifversen, 2007, s. 84-85). Begreber er dermed præget af skiftende politiske og sociale kontekster og må som sådan forstås i deres samfundsmæssige kontekst. De skal således ikke blot forstås som indikatorer af konteksten men også som faktorer, der 'sætter bestemte horisonter og grænser for mulig erfaring og tænkelig teori' (Koselleck, 2007, s. 72).

I forlængelse heraf er konteksten for Koselleck tæt knyttet til tidslighed, som rammes ind af hhv. erfaringsrum og forventningshorisont. Erfaring forstås som 'det nutidige forgangne, hvis begivenheder er blevet indoptaget og kan hentes frem $i$ erindringen. Såvel rationel bearbejdning som ubevidste forestillinger, der ikke eller ikke længere har karakter af viden, forenes i erfaringen. I den enkeltes erfaring er der altid indeholdt og optaget fremmed erfaring, som er formidlet af generationer og institutioner' (Koselleck, 2007, s. 33). Erfaringer er formet af tiden og finder vej ind i begreberne. Forventningen opstår derimod i nutiden som 'nutidigt aktualiseret fremtid, som sigter på et endnu-ikke, på det ikke-erfarede, på det som kan gøres tilgængeligt' (Koselleck, 2007, s. 33). Erfaringsrum og forventningshorisont skaber faktisk og oplevet mulighed for handlen og for hvordan de begreber, der spiller sammen med denne handlen, tilskrives mening.

Koselleck (1990) skelner endvidere mellem tre førsproglige oppositionspar, som ifølge ham danner metahistoriske betingelser for historiens konstitution: 
- Det første par udgøres af det ovenfor beskrevne oppositionspar erfaringsrum/forventningshorisont ( $₫ \varnothing r / s e n e r e)$, hvor Koselleck beskriver, at nutiden findes $i$ spændingsfeltet mellem erfaringsrum og forventningshorisont.

- Det andet oppositionspar betegnes udenfor/indenfor eller sat på spidsen fjende/ven.

- Det tredje oppositionspar betegnes oppe/nede og angiver, at der også inden for et fællesskab er forskel på position. I den forstand angiver oppositionsparret den interne hakkeorden.

Disse tre oppositionspar fungerer som analytiske værktøjer og danner rammen for diskussionen, der følger senere i artiklen.

\section{Metode}

I dette afsnit beskrives den metode, der anvendes i artiklen: (1) Deltagende observation af gymnasielæreres drøftelser af karrierelæring $i$ et udviklingsprojekt omkring karrierelæring, (2) læsning og kodning, (3) analyse og dannelse af meningskategorier i forhold til gymnasielærernes forståelser af karrierelæring. Herefter følger en præsentation af de fremanalyserede meningskategorier og en diskussion af gymnasielærernes forståelser af karrierelæring med afsæt i Kosellecks teoretiske ramme.

\section{Deltagende observation af gymnasielæreres drøftelser af karrierelæring}

Empirien, der danner grundlag for artiklen, er produceret ved deltagende observation af fire forskningscirkelmøder á tre timers varighed, der er afholdt i løbet af udviklingsarbejdet med faget engelsk. Den ene af artiklens forfattere (Skovhus) observerede forskningscirkelmøderne. Ved første forskningscirkelmøde præsenterede Skovhus sig selv og sin rolle i projektet som observat $\varnothing r$ af forskningscirklerne. Ved forskningscirkelmøderne placerede Skovhus sig ved en ledig plads ved det rundbord projektdeltagerne og forskningscirkellederen sad ved, lyttede til hvad der blev sagt og skrev så meget som muligt ned på pc undervejs, herunder hvis der var et perspektiv som hun selv havde bidraget med. Spradley skriver, at når forskeren deltager, får denne 'mulighed for at opleve aktiviteter direkte, får en fornemmelse af hændelsens karakter og registrere sine egne indtryk' (Spradley, 2012, s. 54). Dette karakteriserer den måde, der blev arbejdet med deltagende observation af forskningscirkelmøderne. Med dette perspektiv er det også væsentligt at fremhæve, at observationer ikke sker $i$ et værdineutralt rum men $i$ en situeret praksis, hvor blandt andet forskerens væren og forforståelser bringes ind og ud af feltet: 'I cannot see either myself nor knowledge, in general, as neutral. Once one accepts the contextual nature of being/acting/knowing, it is impossible to think that such being/acting/knowing could be described as neutral. Knowledge, truth, and of course being and acting are always positioned' (Dennis, 2018, s. 56).

Forskerens forforståelse har således konsekvenser for, hvad der bringes videre fra forskningscirklerne og ind i observationsnoterne og dermed for hvad der bliver grundlag for analyserne - og i lige så høj grad, hvad der ikke bringes videre.

I relation til arbejdet med forskningscirklerne kunne Skovhus' forforståelser ses som en særlig udfordring, da karrierelæring netop er et af hendes forskningsfelter. For at afhjælpe denne udfordring 'aflyttede' (Tetler, 2000) Skovhus løbende sig selv - med andre ord gjorde hun sig løbende både forud for observationerne og undervejs bevidst om egne forforståelser af karrierelæring og potentialer $\mathrm{i}$ gymnasieskolen. Gennem denne aflytning søgte Skovhus at arbejde bevidst med, at egne forforståelser af karrierelæring ikke kom til at stå i vejen for at høre, hvad deltagerne sagde, og være åben for de forståelser af karrierelæring, som de gav udtryk for.

I den sammenhæng er det også væsentligt at fremhæve at det, at karrierelæring er et af Skovhus' forskningsfelter, i nogen grad var kendt af deltagerne i udviklingsprojektet. Selvom Skovhus søgte at positionere sig som observat $\varnothing$ r, skete det nogle gange undervejs i forskningscirkelmøderne, at deltagerne eller forskningscirkellederen efterspurgte hendes hjælp til at forstå teoretiske perspektiver på karrierelæring, eksempelvis Hooleys kritiske rammesætning af karrierelæring (Hooley, 2015), som var blevet introduceret ved projektets start ved oplægget fra en professionshøjskole. Skovhus forsøgte i 
disse tilfælde at hjælpe til forståelsen af de teoretiske perspektiver, som deltagerne efterspurgte hjælp til, og trak sig derefter ud af gruppens drøftelse igen.

Umiddelbart efter hvert forskningscirkelmøde gennemgik Skovhus observationsnoterne og udfoldede disse så detaljeret som muligt efter hukommelsen. Trods det at feltnoterne således blev produceret i forskellig tidsmæssig afstand fra det, de beskrev, var de færdiggjort maximalt 24 timer efter forskningscirkelmødet var afholdt. Feltnoterne har den afgørende funktion at fastholde erindringen om, hvad der foregik i felten (Hastrup, 2010, s. 69) og at kunne dele dette med artiklens anden forfatter. Selvom observatøren var bevidst om egen forforståelse og søgte at aflytte sig selv undervejs $i$ feltarbejdet, må feltnoterne stadig ses som udtryk for et selektivt valg af, hvad der er vigtigt og mindre vigtigt. Qua ovenstående tager disse valg afsæt i observatørens forforståelse og de situationelle betingelser.

\section{Læsning og kodning}

Begge artiklens forfattere læste uafhængig af hinanden feltnoterne igennem flere gange og skrev koder $\mathrm{i}$ margin. Koderne blev til i bevægelse mellem artiklens forskningsspørgsmål og en åbenhed og sensitivitet over for hvad der udsprang af praksis som den trådte frem i feltnoterne. Undervejs i kodningen var begge forfattere bevidste om og drøftede indbyrdes egne forforståelser af karrierelæring, og søgte dermed at undgå, at de kom til at stå i vejen for sensitiviteten over for gymnasielærernes forståelser af karrierelæring.

Koderne var endvidere informeret af nærværende artikels forskningsspørgsmål. Dvs. forfatternes læsning af data udfoldede sig inden for rammen af en forskel (forskningsspørgsmål - alt andet), og det er således 'forskellen, der kløver verden i iagttager og iagttaget, og dermed får omverdenen [data] til at træde frem på en bestemt måde' (Åkerstrøm Andersen, 1999, s. 151). Eksempelvis var lærerne og forskningscirkellederne i udviklingsarbejdet optaget af didaktisk rammesætning af karrierelæringsaktiviteter, hvilket forfatterne med de to forskningsspørgsmål, der er ramme for nærværende artikel, ikke er optaget af.

\section{Dannelse af meningskategorier i forhold til gymnasielærernes forståelser af karrierelæring}

Artiklens forfattere mødtes og sammenlignede de producerede koder og deres forskelle og ligheder. Ved denne proces tegnede der sig fem meningskategorier for gymnasielærernes forståelser af karrierelæring, som hver blev navngivet. En oversigt over disse ses i vilkårlig rækkefølge i tabel 1. Det gør sig gældende for alle meningskategorierne, at de på forskellig måde går igen mange gange på tværs af det empiriske materiale og på den måde trådte tydeligt frem i det analytiske arbejde. Alle lærerne giver ikke nødvendigvis udtryk for alle de forståelser af karrierelæring, der afspejles i de fem meningskategorier. ${ }^{\text {iv }}$ 
Tabel 1. Oversigt over gymnasielærernes forståelser af karrierelæring - meningskategorier

\begin{tabular}{l}
\hline Gymnasielærernes forståelser af karrierelæring - meningskategorier \\
\hline Udvidede horisonter \\
Forskellige dimensioner af dannelse \\
Aktør i eget liv \\
Et grænseløst begreb \\
Knas i karrierekommunikationen \\
\hline
\end{tabular}

\section{Præsentation af gymnasielærernes forståelser af karrierelæring}

I dette afsnit præsenteres hver af de fem meningskategorier omkring gymnasielærernes forståelser af karrierelæring. Der er ikke tale om lukkede kategorier, men derimod dynamiske kategorier, der flyder ind over hinanden, blandt andet gennem lærernes italesættelse og forståelse af begrebet. Dette træder frem både i beskrivelsen af meningskategorierne og den efterfølgende diskussion. Det er væsentligt at understrege, at analysen af meningstilskrivelserne ikke er fastlåste men netop er i løbende udveksling.

\section{Meningskategori 1 - Udvidede horisonter}

Flere af lærerne anfører, at arbejdet med karrierelæring kan biddrage til at eleverne får udvidet deres horisont. De nævner forskellige aspekter af horisontudvidelsen, nemlig at eleverne får indsigt i hvad de aktuelle fag kan bruges til uddannelses- og jobmæssigt, at eleverne generelt får udvidet deres horisont $\mathrm{i}$ forhold til hvilke uddannelser og job der findes, samt at den enkelte får udvidet sit perspektiv på, hvad der er muligt for ham eller hende. Som en af lærerne udtrykker det: 'For mig er karrierelæring noget med at udvide deres horisont. Mange kommer med skyklapper på. Jeg vil gerne give dem et bredere blik.'

Endvidere ses karrierelæring som noget, der kan skabe grundlag for at eleverne træffer gode uddannelsesvalg på sigt, hvor gode valg forstås som gode for eleven selv. Blandt andet udtrykker en lærer, at 'Eleverne skal lære at træffe et valg [på et oplyst grundlag] - det valg der er bedst for dem. Det handler også om at vælge noget fra.' En væsentlig pointe for lærerne er her, at eleverne skal få indsigt i at der findes mange veje at gå - at der kan være både gode og dårlige veje for den enkelte, at veje kan være både snørklede og lige, og at forskellige veje kan føre til eksempelvis samme job. Lærerne diskuterer $\mathrm{i}$ den sammenhæng vigtigheden af at være bevidst om risikoen for normativitet $\mathrm{i}$ undervisning med et karriereperspektiv, og fremhæver eksempelvis at lærerens opgave ikke er at sige 'hvad der er rigtigt og forkert, men at vise andre muligheder end dem eleverne kender.'

Omvendt peger lærerne på, at hvis meningen med karrierelæring i gymnasiet er, at lærerne skal gøre eleverne afklarede $\mathrm{i}$ forhold til uddannelsesvalg for at understøtte en tidlig målretning, så tager de afstand fra begrebet. Dette ud fra deres antagelser om, hvad der er den politiske ambition med at indføre karrierelæring på de gymnasiale uddannelser. Her tager de blandt andet afsæt $\mathrm{i}$ både de erfaringer og de forventninger de har til og med det politiske system. Lærerne refererer blandt andet til tidligere reformer både i gymnasieskolen og andre dele af uddannelsessystemet. Eksempelvis spørger en lærer retorisk, om fokus på karrierelæring er udtryk for, at 'fremdriftsreformen nu er kommet ud på gymnasierne?'.

\section{Meningskategori 2 - Forskellige dimensioner af dannelse}

Lærerne fremhæver, at det er meningsfuldt at forstå karrierelæring som dannelse $i$ en gymnasiekontekst. I lærernes drøftelser træder følgende tre dimensioner af dannelse frem: 1) Dannelse i forståelsen af at eleven får åbnet sin verden; 'Det er dannende i sin essens at eleverne hører noget andet end de har hørt før.' 2) Dannelse i forståelsen at eleverne forholder sig til, hvad der er vigtigt i livet, hvad de gerne vil med deres liv og hvem de gerne vil være i livet. 3) Dannelse i forståelsen at eleverne udvikler kritisk medborgerskab, herunder at de forholder sig til sig selv i samfundet og til fælles 
samfundsmæssige problemstillinger, og udvikler perspektiver på mulige handlinger. Som en lærer formulerer det, skal de med andre ord 'blive til nogen, frem for noget - Det handler om, hvem man vil være frem for hvad man vil være.'

Lærerne udtrykker, at man politisk set har nedprioriteret gymnasiets dannelsesopgave gennem mange år som følge af et fremtrædende nytteperspektiv på uddannelser. Lærerne ser karrierelæring som en måde at legitimere og genintroducere dannelsesdimensionen. Én lærer siger at '(...) almen dannelsen er tilbage. Det er tilladt at bruge tid på identitetsspørgsmål i undervisningen. Det er en lettelse efter mange år med kompetencemål. Det tror jeg vil tiltale mange.' Nogle lærere ser dog også udfordringer ved at sammentænke karrierelæring og dannelse. De peger på, at en udfordring er, at politikkerne 'vil tage afstand fra vores måde at tænke det på. Karriere forstås politisk som protestantisk arbejdsmoral.' I og med at lærerne antager, at dannelsesperspektivet er i opposition til den politiske ambition med karrierelæring oplever de, at en dannelsesforståelse af karrierelæring vil skulle retfærdiggøres over for politikere.

Omvendt siger nogle lærere, at hvis karrierelæring skal forstås som dannelse, så er det vigtigt at huske, at de har arbejdet med dannelse hele tiden. I forlængelse af dette perspektiv mener lærerne ikke, at karrierelæring giver dem anledning til at forandre undervisningen, hvorfor det bliver svært for dem at se, hvor udviklingspotentialet og 'det nye' i karrierelæring er. Dette betyder dog ikke, at de ikke gør fors $\varnothing$ get.

\section{Meningskategori 3 - Aktør i eget liv}

Mange af lærerne på tværs af det empiriske materiale udtrykker, at karrierelæring overordnet set kan understøtte, at eleven bliver livsduelig og aktør i eget liv ved at lære dem at reflektere over og begrunde valg og fravalg i livet. Perspektivet formuleres af en lærer i det følgende citat: 'Eleverne skal lære at leve deres liv på den bedste måde (...). Det handler om at være aktør i eget liv - egentlig er det eksistentialisme.' Lærerne fremhæver at karrierelæringsperspektivet kan inspirere til at rammesætte undervisningen, så eleverne understøttes i at forbinde undervisningens indhold med deres eget liv og det fælles samfundsmæssige liv.

Lærerne formulerer dog også, at refleksion med disse individuelle perspektiver kan have en skyggeside. Et for stort fokus på, at eleverne skal perspektivere indholdet $\mathrm{i}$ undervisningen til eget liv kan fostre, at eleverne kommer til at tale for meget om sig selv og problematikker i eget liv. Det kan være hårdt for eleverne hele tiden at skulle kigge ind $\mathrm{i}$ eget liv. Perspektivet afspejles eksempelvis $\mathrm{i}$ denne ordveksling mellem to lærere; 'Undervisning skal ikke være terapi' 'Nej, der bliver kø ved psykologen. Det må ikke være søgt.'

\section{Meningskategori 4 - Et grænseløst begreb}

Som skrevet ovenfor kan karrierelæring i lærernes forståelse både rumme udvidelse af horisonter, dannelse, uddannelsesvalg og dét at være aktør i eget liv. Lærerne udtrykker i forlængelse heraf tvivl om, hvorvidt det er hensigtsmæssigt at arbejde med et begreb, hvor der ikke er en grænse for, hvad det reelt rummer og ikke rummer. Denne overvejelser formuleres eksempelvis således af en lærer: 'Udvander vi karrierelæring, fordi vi arbejder så bredt med det?' Lærernes tvivl og skepsis i forhold til den brede begrebsforståelse kommer også til syne $\mathrm{i}$ analyse og diskussioner af konkrete undervisningsforløb, som præsenteres gennem forskningscirklerne. En lærer rejser blandt andet følgende kritik af et præsenteret forløb: 'Kan dette kaldes karrierelæring? Hvor går grænsen? Når vi arbejder med dannelsesprojekter, hvornår er der så ikke tale om karrierelæring mere?' Lærerne betoner, at de manglende grænser for, hvor karrierelæring starter og slutter bevirker, at begrebet dermed kan rumme alt, og således bliver meningsløst. I forlængelse heraf stiller lærerne spørgsmål ved, hvorvidt det er meningsfuldt at integrere et begreb som karrierelæring i gymnasieskolen. 


\section{Meningskategori 5 - Knas i karrierekommunikationen}

Lærerne problematiserer karrierelæringsbegrebet ordlyd. De fremhæver, at ordet 'karriere' i sig selv spænder ben for kommunikationen med eleverne (og kollegaerne uden for udviklingsprojektet), fordi begrebet hverdagssprogligt konnoterer dét at have fokus på at være målrettet og stige i graderne. Lærerne fremhæver, at hvis de i undervisningen anvender begrebet karrierelæring sammen med eleverne, vil eleverne forstå det som noget der entydigt handler om uddannelsesvalg - altså en smallere forståelse end den som lærerne i udviklingsprojektet har. Som én lærer konkluderer, skal der 'laves nogle krumspring for at få eleverne til at forstå, at karrierelæring er noget andet end det eleverne umiddelbart forstår ved ordet.' Med andre ord forventer lærerne, at eleverne kobler karrierelæring på den gængse hverdagsforståelse af begrebet, hvorved eleverne vil tro at de igennem undervisningen skal målrettes og træffe et uddannelsesvalg, hvilket netop er den forståelse af karrierelæring som lærerne tager afstand fra.

Lærerne kan altså se potentialer i begrebet i forhold til undervisningen men fremhæver samtidig, at selve begrebets ordlyd kan mudre kommunikationen og sende nogle forkerte signaler om formålet med karrierelæring.

I forlængelse af disse overvejelser er det også en gennemgående drøftelse, hvorvidt lærerne skal præsentere eleverne for begrebet i undervisningen, eller om det er mere hensigtsmæssigt at arbejde med at underst $\varnothing$ tte elevernes karrierelæring uden at præsentere dem for begrebet som sådan. Lærerne har valgt forskellige tilgange. Nogle lærere har fortalt eleverne, at det 'oppefra er bestemt at der skal arbejdes med karrierelæring', og på hvilken måde hun og de andre lærere forstår og arbejder med begrebet. Andre lærere har valgt at arbejde med karrierelæring i undervisningen uden at præsentere eleverne for begrebet. En lærer sammenligner det med at arbejde med en dannelsesdimension $\mathrm{i}$ undervisningen: 'Jeg taler heller ikke om almen dannelse med dem - men jeg arbejder med det i min undervisning.' Der er således en løbende drøftelse af, hvorvidt karrierelæring skal være en del af en åben eller skjult læreplan. Lærerne diskuterer i forlængelse heraf, hvorvidt en manglende italesættelse af karrierelæring kan medvirke til, at lærerne glemmer begrebet, hvormed det ikke integreres i praksis og således mister sin betydning.

\section{Diskussion}

Analyserne af datamaterialet viser, at begrebet karrierelæring bærer mange medbetydninger, som trækker tråde til både praksis, forståelse af det at være gymnasielærer og politik. Begrebet er med Kosellecks terminologi transferabelt, forstået som at det overtages, anvendes og oversættes af mange forskellige grupper i mange forskellige sammenhænge (Koselleck, 1985, s. 160). Lærerne arbejder med at overføre karrierelæringsbegrebet fra et policyniveau til et praksisniveau i en gymnasial sammenhæng. Analysen viser, at denne oversættelse ikke sker gnidningsfrit men igennem en kamp om at besætte, overtage og anvende begrebet og dermed gøre det relevant for lærernes praksis og det formål de tilskriver gymnasiet. Koselleck skriver, at denne proces foregår asymmetrisk mellem fortid og fremtid erfaring og forventning - og at forventninger til fremtiden konstitueres af 'Håb og frygt, ønske, vilje og bekymring, men også rationel analyse, receptiv skuen og nysgerrighed' (Koselleck, 2007, s. 33).

Som de fem meningskategorier viser, ser lærerne sig i en vis udstrækning som værende i opposition til det policyniveau, der har indskrevet begrebet karrierelæring i policydokumenter for gymnasieskolen. Koselleck præsenterer oppositionsparret indenfor/udenfor eller mere spidst formuleret som skellet mellem ven/fjende. Gymnasielærerne i de tre gymnasieformer forstår i denne sammenhæng sig som nogen, der står sammen 'indenfor' om at arbejde for gymnasieelevernes dannelse, udvikling af agens i eget liv og udvidede horisonter. De skaber hermed en kollektiv identitet som 'gymnasielærere' og en fælles forståelse af hvad en gymnasial uddannelse er, samt kan og skal bruges til. De står dermed i opposition til det ydre, som for lærerne i denne sammenhæng er Undervisningsministeriet. Ministeriet tilskrives blandt andet et ønske om at få lærerne til at målrette og uddannelsesafklare eleverne - noget som lærerne mener kan føre til et yderligere pres på eleverne. Formuleret ved Åkerstrøm Andersen: 
'Indenfor står vi last og brast om vores velfærd. Udenfor er de eller det som truer vores [her gymnasieelevernes] velfærd' (Åkerstrøm Andersen, 1999, s. 82). Grænsen mellem indenfor og udenfor er ikke stabil i datamaterialet men forhandles kontinuerligt. Denne forhandling udfordres af, at lærerne ikke konkret har kendskab til Undervisningsministeriets forståelse af begrebet karrierelæring, idet det ikke er defineret i tilgængelige policy dokumenter, ligesom de ikke har kendskab til ministeriets dagsorden med at indføre karrierelæring i gymnasiet. Lærernes forhandlinger om aktuelle grænsedragninger styres blandt andet af deres erfaringer med og forventninger til policy på uddannelsesområdet.

Analyserne viser, at lærerne som nævnt kan se potentialer $\mathrm{i}$ at arbejde med karrierelæring $\mathrm{i}$ forståelsen 'udvidede horisonter', 'dimensioner af dannelse' og 'aktør i eget liv'. Med afsæt i deres antagelser om, hvad der er Undervisningsministeriets dagsorden med at indføre karrierelæring $\mathrm{i}$ gymnasiet, har lærerne dog vanskeligt ved at fastholde de nævnte potentialer som legitime forståelser af karrierelæring. Dermed får de vanskeligt ved at fastholde, at man som gymnasielærer med disse måder at forstå karrierelæring på lever op til de forpligtelser, man som professionel har i forlængelse af loven.

Ydermere bliver lærerne fanget af deres erfaringer med en hverdagssproglig forståelse af karriere som uddannelses- og jobvalg, målretning og hierarkisk progression. Denne erfaring udfordrer deres egen oplevelse af begrebets meningsfuldhed i gymnasieskolen. En lærer udtrykker dette spændingsfelt mellem erfaringsrum og forventningshorisont således ' $V i$ er enige om at tænke dannelsesvejen, men vi falder hele tiden i og taler om job. Den dukker op hele tiden. Er vi så fastlåste i vores tankegang?'. Samtidig fremgår det af datamaterialet, at lærerne fremhæver, at en meningsfuld anvendelse og oversættelse af karrierelæringsbegrebet i kommunikation med elever og kollegaer udfordres af hverdagsforståelsen af karriere.

Lærerne har dermed to spor $\mathrm{i}$ deres nutidige aktualisering af karrierelæring som formuleres $\mathrm{i}$ spændingsfeltet mellem erfaringsrum og forventningshorisont. I det ene spor formuleres karrierelæring i tilknytning til en insisteren på hvad de som gymnasielærere vil, hvad der er vigtigt i deres professionelle virke og for gymnasieskolen mere alment. I det andet spor formuleres karrierelærings muligheder (og begrænsninger) inden for lærernes erfaringer med og forventninger til det politiske system og hverdagsforståelsen.

Lærernes arbejde med at meningstilskrive begrebet karrierelæring udfordres af, at begrebet ikke er klart defineret i policydokumenter og i den gymnasiale kontekst. Begrebet karrierelæring bliver i den forstand en tom kategori, som er i bevægelse og som kontinuerligt må fyldes med en ny mening. Koselleck fremhæver, at når brugen af et flertydigt begreb (i dette tilfælde karrierelæring) er uvis, kan det sigte mod alt, således at intet indhold kan udelukkes. Modsat kan begrebet gives en særlig kvalitet hvormed grænser optegnes, der dog ikke fremgår direkte af begrebet (Koselleck, 2007, s. 145). Lærerne fremhæver og er kritiske overfor, at begrebet karrierelæring er så bredt, at det i praksis kan indeholde alt, hvormed det bliver meningsløst. Dermed fremstiller lærerne karrierelæring som det, Irving med en kritisk stemme refererer til som et 'catch-all-term' (Irving, 2015, s. 299). Omvendt arbejder lærerne aktivt med at tillægge begrebet en særlig kvalitet - nemlig genlegitimering af dannelsesperspektivet i undervisningen, at understøtte at eleverne bliver aktører i eget liv og udvide deres horisonter. Dermed optegner lærerne selv grænserne for karrierelærings mulighedsrum med afsæt i et $\emptyset$ nske om at besætte begrebet med nogle forståelser, de oplever som meningsfulde. Som beskrevet indledningsvist arbejdes der $\mathrm{i}$ internationale og nordiske sammenhænge med at udvikle teoretiske og empirisk baserede forståelser af eksempelvis karrierelæringsbegrebet, der er hjælpsomme for både policy og praksis. Analyserne indikerer, at trods lærernes præsentation af disse perspektiver (oplæg ved professionshøjskole) og arbejde med at gøre begrebet meningsfuldt, så ophæver det ikke den udfordring de oplever i forbindelse med deres antagelse om, at Undervisningsministeriets forståelse af begrebet er en anden, og at de derfor ikke nødvendigvis lever op til bekendtgørelsen med deres egen grænsedragning. 
Forskelligheden i gymnasieformerne spiller en rolle i diskussionerne af, hvordan karrierelæring kan inddrages i undervisningen. Koselleck beskriver oppositionsparret oppe/nede, der overordnet set kendetegner de mulige positioneringer, der opstår inden for et fællesskab (Koselleck, 2007, s. 173). Af det empiriske materiale fremgår det, at positionerne i forskningscirkelgruppen er flydende. De kommer løbende til udtryk igennem en hierarkisering af, hvilken af de tre gymnasieformer, hhv. stx, htx og hhx, der har 'lettest' ved at integrere karrierelæring i de tre forståelser - 'udvidede horisonter', 'dimensioner af dannelse' og 'aktør i eget liv' - ind i deres etablerede og potentielle fremtidige praksis. Lærerne henviser både til gymnasieformen og til antagelser om typen af gymnasieelever. Eksempelvis antages dimensionen 'udvidede horisonter' i forhold til uddannelse og job at være lettest for lærere på hhx at integrere i gymnasieformen som helhed, mens det antages at være lettest at arbejde med 'dannelse' på stx. De løbende forhandlinger om grænsedragninger for begrebet karrierelæring påvirker dermed de interne forståelser - ikke af hvem der er oppe og hvem der er nede, men derimod af hvem der har de letteste og vanskeligste vilkår for at arbejde med begrebet ind i praksis.

\section{Afsluttende bemærkninger}

Analysen baserer sig på en kort tidsperiode, nemlig de ni måneder som forskningscirkelmøderne løb over. Vi undersøger således et begrebs betydning og brug til en bestemt tid modsat Koselleck som undersøger længere komplekse historiske tidsforløb. Vi ønsker at fremhæve, at trods det at empirien er produceret i et projekt med en forholdsvis kort tidsperiode, så har de valgte dele af begrebsapparatet en udsigelseskraft $\mathrm{i}$ forhold til at fremanalysere og diskutere de kampe, der foregår omkring en semantisk besættelse af et komplekst begreb som karrierelæring.

Artiklens analyser og diskussion giver indblik i gymnasielæreres meningstilskrivelser af karrierelæring som et nyindført begreb i gymnasieskolen. Endvidere giver analyserne og diskussionen indblik i de udfordringer, der kan opstå, når der i policydokumenter indskrives begreber, som ikke defineres klart. Med Koselleck er det dog vigtigt at hæfte sig ved, at begreber qua deres flertydighed, som netop er det der karakteriserer et begreb, altid vil skulle integreres gennem en forhandling af mening. Som analysen har vist er denne forhandling af mening kompleks og fyldt med indre og ydre paradokser. I gymnasielærernes oversættelse af policy til praksis opstår der et fortolkningsvakuum, der gør det udfordrende at operationalisere karrierelæring i en undervisningspraksis.

Fortolkningsvakuummet forstærkes af, at uddannelsessystemet, som gymnasieskolen er en del af, og arbejdsmarkedet er komplekse og stærkt politiserede felter. De mange mulige betydninger og spændingerne i forhandlingen af karrierelæringsbegrebet er derfor også udtryk for, at begrebet netop taler ind i et komplekst og politiseret felt, forankret i værdier, diskurser og filosofiske forståelser af, hvad uddannelse er til for. - Hvorfor holder vi skole? Hvad er formålet med uddannelse? Hvem skal vi uddanne? Hvad skal vi uddanne til? Hvordan opretholder vi et velfærdssamfund? Disse og lignende spørgsmål som karrierelæringsbegrebet knytter sig til besvares eller løses ikke ved at 'få styr på begrebet' - spændingerne i feltet og blandt aktørerne vil kontinuerligt være tilstede. Fortolkningerne trækker på lærernes, politikkernes, elevernes og borgernes erfaringsrum og forventningshorisont. De finder således sted i nutiden, men trækker på, hvad der allerede er sket, sagt og gjort, og påvirker dermed muligheder i fremtiden. Det må derfor forventes, at de semantiske kampe om at besætte og generalisere begrebet fortsætter.

Trods denne vedvarende spænding omkring forhandlingen af begrebet karrierelæring, henleder analyserne også opmærksomheden på, at der i praksis er en velvilje og ønske om at besætte begrebet. Samtidig ser det også ud til, at det kunne være væsentligt, at policy-niveauet i en vis udstrækning præciserer forståelsen af begrebet. En sådan præcisering kan få betydning for det praksisudviklings- og forandringspotentiale, som begrebet bærer med sig. 


\section{Referencer}

Arthur, N., Collins, S., Marshall, C., \& McMahon, M. (2013). Social justice competences and career development practices. Canadian journal of counselling and psychotherapy, 47(2), 136-154.

Dennis, B. (2018). Tales of Working Without/Against a Compass. I The Wiley Handbook of Ethnography of Education (s. 51-70). Wiley-Blackwell.

Hastrup, K. (2010). Feltarbejde. I Kvalitative metoder (1. udg.). Hans Reitzels Forlag.

Haug, E. H. (2018). Karrierekompetanser, karrierelæring og karriereundervisning. Fagbokforlaget.

Hooley, T. (2013). Career development in Canada. International Centre for Guidance Studies.

Hooley, T. (2015). Emancipate yourselves from mental slavery. Self-actualisation, social justice and the politics of career education.

https://derby.openrepository.com/bitstream/handle/10545/579895/Hooley+-

+Emancipate+Yourselves+from+Mental+Slavery.pdf

Hughes, D., Mann, A., Barnes, S.-A., Baldauf, B., \& McKeown, R. (2016). Careers education: International literature review. Warwick Institute for Employment Research/Education and Employers Research. https://cica.org.au/wp-content/uploads/Careers-education-International-literature-review.pdf

Ifversen, J. (2007). Begrebshistorien efter Reinhart Koselleck. Slagmark - tidsskrift for idéhistorie, 81103. https://doi.org/10.7146/sl.v0i48.68

Irving, B. A. (2015). Locating social in/justice within career education in New Zealand high schools: A critical exploration [University of Otago]. https://ourarchive.otago.ac.nz/bitstream/handle/10523/5929/IrvingBarrieB2015PhD.pdf

Kompetanse Norge. (2019). Nasjonalt kvalitetsrammeverk for karriereveiledning. Faglig forslag til områdene etikk, karrierekompetanse og kompetansestandarder. https://www.kompetansenorge.no/globalassets/karriere/rapport-nasjonalt-kvalitetsrammeverkfor-karriereveiledning.pdf

Koselleck, R. (1985). Futures past: On the semantics of historical time. MIT Press.

Koselleck, R. (1990). Sprogændring og begivenhedshistorie. Den jyske historiker, 50, 121-135.

Koselleck, R. (2007). Begreber, tid og erfaring. Hans Reitzels Forlag.

Lejonberg, E., \& Føinum, M. (2018). Hva er god veiledning? Fagbokforlaget.

Linné, A. (2015). Curriculum theory and didactics - towards a theoretical rethinking. Nordic Journal of Studies in Educational Policy, 2015(1), 31-39. https://doi.org/10.3402/nstep.v1.27002

Nevers, J., \& Olsen, N. (2007). Indledning. I Begreber, tid og erfaring. Hans Reitzels Forlag.

Persson, S. (2009). Forskningscirklar-En vägledning. Resurscentrum för mångfaldens skola. http://muep.mau.se/bitstream/2043/7155/1/forskningscirklar\%20\%20en\%20v\%C3\%A4gledning.pdf

Plant, P. (2009). Fæste. Dansk uddannelses- og erhvervsvejledning 1886-2009. Studie og Erhverv.

Plant, P., \& Kjærgård, R. (2016). From mutualism to individual competitiveness: Implications and challenges for social justice within career guidance in neoliberal times. Journal of the National Institute for Career Education and Counselling (NICEC), 36, 12-19.

Pryor, R. G. L., \& Bright, J. E. H. (2014). The chaos theory of careers (CTS): Ten years and only just begun. Australian Journal of Career Development, 23(1), 4-12. https://doi.org/10.1177/1038416213518506

Regeringen, Socialdemokraterne, Dansk Folkeparti, Liberal Alliance, Det Radikale Venstre, Socialistisk Folkeparti, \& Det Konservative Folkeparti. (2016). Aftale mellem regeringen, Socialdemokraterne, Dansk Folkeparti, Liberal Alliance, Det Radikale Venstre, Socialistisk Folkeparti og Det Konservative Folkeparti om styrkede gymnasiale uddannelser. http://www.dpt.dk/wpcontent/uploads/2016/06/160603-Styrkede-gymnasiale-uddannelser.pdf

Skovhus, R. B. (2018). Vejledning-Valg og læring [Career guidance: Choice and learning]. Trykværket. 
Spradley, J. P. (2012). Deltagerobservation. I Deltagerobservation. En metode til undersøgelse af psykologiske fænomener. Hans Reitzels Forlag.

Sultana, R. G. (2013). Career education: Past, present ... But what prospects? British Journal of Guidance \& Counselling, 41(1), 69-80. https://doi.org/10.1080/03069885.2012.739373

Tetler, S. (2000). Imellem integration og inklusion: Om nødvendigheden af at udvikle rummelighedens didaktik: Ph.d.-afhandling. Danmarks Lærerhøjskole.

Thomsen, R. (2014). Karrierekompetence og vejledning i et nordisk perspektiv-Karrierevalg og karrierelæring [Concept note]. NVL \& ELGPN.

Tveit, A. D. (2009). A parental voice: Parents as equal and dependent - rhetoric about parents, teachers, and their conversations. Educational Review, 61(3), 289-300.

https://doi.org/10.1080/00131910903045930

Undervisningsministeriet. (2016). Lov om de gymnasiale uddannelser. LOV nr 1716 af 27/12/2016.

Undervisningsministeriet. (2019). Oversigt over de gymnasiale uddannelser [Ug.dk]. https://www.ug.dk/6til10klasse/hvilken-gymnasial-uddannelse-skal-jeg-vaelge

Watts, A. G. (2011). Reflection note: Sixth international symposium on career development and public policy. http://iccdpp.org/wp-content/uploads/2014/02/IS2011-Reflection-Note.pdf

Åkerstrøm Andersen, N. (1999). Diskursive analysestrategier: Foucault, Koselleck, Laclau. Luhmann. Nyt fra Samfundsvidenskaberne.

\footnotetext{
i Amerikanske Frank Parsons angives ofte at være karrierevejledningens grundlægger. I Danmark blev karrierevejledningens tidligste stadier udviklet af Alfred Lehmann (1858-1921) og Poul Bahnsen (1899-1960) (Plant, 2009, s. 22-23).

ii Vi vælger her at anvende begrebet karrierevejledning, frem for eksempelvis career education eller career development, da karrierevejledning er det mest anvendte begreb i Danmark.

iii Vi vælger denne oversættelse og præsentation af 'Begreb (mening)', da vi i artiklen analyserer et begrebs meningstilskrivelse og ikke hvordan et ord bliver til et begreb.

iv I det nedenstående skrives for den sproglige variations skyld 'lærerne', 'mange lærere', 'nogle lærere' uden at det skal forstås som kvantitative angivelser.
} 